\title{
HUBUNGAN KELELAHAN KERJA DENGAN KINERJA PERAWAT DI BANGSAL RAWAT INAP RUMAH SAKIT ISLAM FATIMAH KABUPATEN CILACAP
}

\author{
Dian Kurniawati, Solikhah \\ Fakultas Kesehatan Masyarakat, Universitas Ahmad Dahlan, Yogyakarta
}

\begin{abstract}
Background: human reseources needed in hospitals provide care to the patient, the nurse workforce. The nurse was human resources that occupy the top in terms of the number of order thoughout the hospital. One the problems in worked on each worker that was exhausted. Problems in work can effect the level of performance of a worker. With the performance assessment we can know the performance levels that are generated on each worker in the work.

Methods: this study used methods of observastional analytic cross-sectional approach with cross. Technique sampling used totally sampling, the sampling as a whole to serve as responder research. Data obtaind from the questionnaire the conducted analysis of chi-square with a $95 \%$ level of value $(p<0,05)$.

Results: based on results of research is the relationship between the fatigue of work performance wiyh the result 0,038 " or value $\mathrm{p}$ the $\mathrm{Ho}<0.05 \mathrm{Ha}$ was rejected and accepted, than there is a significant relationship between the fatigue of work performance. Magnitude of the relationship of two variables is $2,26 \%$. Relationship between the fatigue of work with high performance was not good, but on a very meaningful work fatigue experienced low relationship that is less meaningful because, get results with low fatigue performance are not good. The level of errors in the generate 1,441.

Conclucions: (a) there was a significant relationship between the fatigue performances of working with nurses in the inpatient ward. (b) A high work fatigue more dominant has a relationship to the performance of the nurse.
\end{abstract}

Keyword: job burnout, performance, Nurses

\section{PENDAHULUAN}

Sumber daya manusia yang dibutuhkan rumah sakit dalam memberikan perawatan terhadap pasien antara lain yaitu tenaga perawat. Perawat merupakan sumber daya manusia yang menempati urutan teratas dari segi jumlah di seluruh rumah sakit. Khususnya pada perawat bangsal rawat inap, mereka lebih harus mementingkan kesembuhan pasien dalam perawatannya, sehingga pasien sangat mengharapkan kinerja seorang perawat yang maksimal. Keberhasilan suatu organisasi ditentukan oleh dua faktor, yakni sumber daya manusia/karyawanya atau tenaga kerjanya, saranan dan prasarana atau fasilitas kerjanya. Secanggih dan selengkap apapun fasilitas pendukung yang dimiliki suatu organisasi kerja, tanpa adanya sumber daya manusia yang memadai, baik jumlah maupun kemampuan maka niscaya organisasi tersebut berhasil mewujudkan visi, misi dan tujuan organisasinya. Kualitas sumber daya manusia atau karyawan tersebut diukur dari kinerja karyawan tersebut (Notoatmodjo, 2007).

Kinerja sebenarnya sama dengan prestasi kerja, kinerja merupakan hasil kerja dan bagaimana proses pekerjaan berlangsung (Wibowo, 2010). Seseorang perawat dapat memiliki kinerja yang baik apabila perawat dapat melakukan pekerjaan dengan baik dan hasil kerjanya sesuai dengan apa yang harus dicapainya. Beberapa faktor yang dapat mempengaruhi kinerja antara lain faktor individu pekerja, faktor organisai, faktor psikologis (Notoadmodjo, 2007). Salah satu yang sering dapat sebagai sebab menurunnya kinerja adalah keterampilan 
atau kemampuan seorang pekerja dalam bekerja. Kemampuan seorang pekerja dipengaruhi oleh banyak faktor salah satunya adalah tingkat pendidikan dan lama kerja mereka (Notoatmodjo, 2009).

Kinerja perawat tidak hanya dilihat dari faktor keterampilan saja, banyak berbagai faktor lain yang dapat mempengaruhi seperti halnya beban kerja yang terus meningkat serta umur yang kurang mendukung untuk bekerja secara maksimal Beban kerja yang terus meningkat harus didukung oleh keadaan fisik seorang pekerja, dimana umur merupakan slaah satu faktor yang menentukan keadaan fisik pekerja tersebut mendukung. Umur harus mendapat perhatian karena akan dapat mempengaruhi kondisi fisik, mental, kemapuan kerja dan tanggung jawab seseorang (Hasibuan, 2010).

Bertambahnya beban kerja seorang serta keadaan fisik yang kurang mendukung, perawat saat bekerja dapat merasakan kelelahan. Banyak penelitian menunjukan bahwa faktor individu dalam hal ini antara lain umur, masa kerja, status perkawinan dan gizi mempunyai pengaruh menimbulkan kelelahan (Eraliesa, 2009). Kelelahan kerja merupakan salah satu faktor penurunan kinerja yang dapat menambah tingkat kesalahan dalam bekerja (Nurmianto, 1996). Kelelahan kerja yang tidak diatasi dapat menimbulkan berbagai permasalahan kerja yang fatal dan mengakibatkan kecelakaan dalam bekerja. Sehingga dapat dipastikan suatu rumah sakit wajib mengetahui tingkat kinerja dan hal yang dapat menimbulkan permasalahan dalam bekerja yaitu antara lain kelelahan kerja yang dialami secara umum pada karyawan, dan salah satunya pada perawat.

\section{Tinjauan Pustaka \\ Kelelahan kerja}

Kelelahan adalah suatu mekanisme perlindungan tubuh agar tubuh menghindari dari kerusakan lebih lanjut (Suma'mur, 1995). Menurut Chavalitsakulchai dan Shahvanaz (1991) dalam Setyawati (2010), kelelahan kerja merupakan fenomena yang kompleks yang disebabkan oleh faktor biologi pada proses kerja serta dipengaruhi oleh faktor internal maupun eksternal. Faktor internal pengaruh terjadinya kelelahan kerja yaitu lingkungan kerja yang tidak memadai, dan eksternal pengaruh kelelahan kerja yaitu masalah psikososial (Setyawati, 2010). Kelelahan kerja menunjukan keadaan yang berbeda-beda tetapi semuanya berkaitan kepada penggurangan kapasitas kerja dan ketahanan umum (Wijaya \& Setyawati. 2006).

Semua pekerjaan akan menghasilkan kelelahan kerja, dan kelelahan kerja akan menurunkan kinerja serta menambah tingkat kesalahan kerja (Nurmianto, 1996). Setiap orang yang bekerja dengan melebihi batas tertentu akan menimbulkan kelelahan, oleh karena itu setiap perusahaan haruslah memikirkan waktu istirahat sebelum tenaga pulih kembali (Nitisemito, 1996).

Menurut Setyawati (2010), faktor-faktor yang dapat mempengaruhi terjadinya kelelahan kerja terdiri dari faktor lingkungan kerja yang tidak memadai untuk bekerja dan masalah psikososial mereka ataupun fisik mereka. Fisik seorang pekrja dapat dipengaruhi oleh tingkatan umur, karyawan muda umumnya memiliki kemampuan fisik yang lebih kuat dibandingkan dengan karyawan yang berumur lebih tua (Hasibuan,2009). Didalam buku Suma'mur (1995), sebab-sebab kelelahan kerja terdiri dari :

1. Monoton/melakukan pekerjaan yang sama setiap waktunya

2. Beban kerja yang tinggi dan lama kerja

3. Lingkungan yang kurang mendukung

4. Faktor kejiwaan pekerja

5. Sakit, rasa sakit, dan gizi buruk seorang pekerja

Menurut Suma'mur (1995), Tanda-tanda kelelahan yang utama adalah hambatan terhadap fungsi-fungsi kesadaran otak dan perubahan-perubahan pada 
organ-organ di luar kesadaran serta proses pemulihan. Orang yang lelah mengalami, penurunan perhatian, perlambatan dan hambatan persepsi, lambat dan sukar berpikir, penurunan kemampuan atau dorongan untuk kerja, kurangnya efisiensi kegiatan-kegiatan fisik dan mental.

Beberapa hal yang patut mendapat perhatian dan diselenggarakan sebaikbaiknya agar kelelahan kerja dapat dikendalikan menurut Setyawati (2010), antara lain:

1. Lingkungan kerja yang bebas dari zat-zat yang berbahaya, pencahayaan yang memadai sesuai dengan jenis pekerjaan yang dihadapi pekerja, pengaturan udara di tempat kerja yang adekuat di samping bebas dari kebisingan dan getaran.

2. Waktu kerja yang berjam-jam harus diselingi oleh istirahat yang cukup untuk makan dan keperluan khusus lain.

3. Kesehatan umum pekerjaan harus baik dan selalu dimonitor, khususnya untuk daerah tropis dimana banyak pekerja yang cenderung mengalami kekurangan gizi dan menderita penyakit serius.

4. Disarankan pula agar kegiatan yang menegangkan dan beban kerja yang berat tidak terlalu lama.

5. Jarak tempat tinggal dan tempat kerja diusahakan seminimal mungkin dan bila perlu dicarikan alternatif penyelesaiaanya, yaitu berupa pengadaan transportasi bagi pekerja dari dan ke tempat kerja.

6. Pembinaan mental para pekerja di perusahaan secara teratur maupun berkala dan khusus perlu dilaksanakan dalam rangka stabilitas direncanakan secara baik dan berkesinambungan.

7. Perhatian khusus bagi kelompok pekerja tertentu perlu diberikan, yaitu kepada pekerja muda usia, wanita yang hamil dan menyusui, pekerja usia lanjut, pekerja yang menjalani shift kerja malam, pekerja yang baru pindah dari bagian lain.

8. Pekerja-pekerja bebas dari alkohol maupun obat-obatan yang membahayakan serta yang menimbulkan ketergantungan.

\section{Kinerja}

Kinerja berasal dari pengertian performance. Kinerja juga memiliki pengertian performance sebagai hasil kerja atau prestasi kerja. Sebenarnya kinerja mempunyai makna yang lebih luas, bukan hanya hasil kerja, tetapi termasuk bagaimana proses pekerjaan berlangsung (Wibowo, 2010). Menurut Pabundu (2006), pengertian kinerja telah dirumuskan sebagai hasil-hasil fungsi pekerja/ kegiatan seseorang atau kelompok dalam suatu organisasi yang dipengaruhi oleh berbagai faktor untuk mencapai tujuan organisasi dalam periode waktu tertentu.

Faktor-faktor yang menentukan kinerja seseorang menurut Notoatmodjo (2007), dikelompokkan menjadi 3 faktor antara lain:

1. Variabel individu yang terdiri dari: kemampuan dan keterampilan, latar belakang keluarga, tingkat sosial ekonomi, dan demografis (umur, jenis kelamin, etnis dan sebagainya).

2. Variabel organisasi yang terdiri dari: sumber daya, kepemimpinan, imbalan, struktur, dan desain pekerjaan

3. Variabel psikologis yang terdiri dari: persepsi, sikap, kepribadian, belajar dan motivasi. Secara umum kinerja seorang karyawan atau tenaga kerja dipengaruhi oleh motivasi, kemampuan dan faktor persepsi.

\section{Penilaian kinerja}

Penilaian kinerja (performance assessment) adalah proses yang mengukur kinerja karyawan (Simamora, 1995). Penilaian kinerja dilaksanakan untuk sebuah kegiatan yang dapat memperbaiki keputusan-keputusan personalia dan 
memberikan umpan balik kepada para karyawan tentang pelaksanaan kerja mereka (Handoko, 2001). Penilaian kinerja dimaksudkan untuk mengukur kinerja masing-masing tenaga kerja dalam mengembangkan kualitas kerja, pembinaan selajutnya, tindakan perbaikan atas pekerjaan yang kurang sesuai dengan deskripsi pekerjaan, serta untuk keperluaan yang berhubungan dengan masalah ketenagakerjaan lainnya (Sostrohadiwiryo, 2005).

Tujuan dilakukannya penilaian kinerja secara umum adalah untuk memberikan feedback kepada pegawai dalam upaya memperbaiki tampilan kerjanya dan upaya meningkatkan produktivitas organisasi, dan kebijakan terhadap pegawai seperti untuk tujuan promosi, kenaikan gaji, pendidikan, latihan dan lain-lainnya. Penilaian kinerja dapat menjadi landasan untuk penilaian sejauh mana kegiatan MSDM seperti perekrutan, seleksi, penempatan, dan pelatihan dilakukan dengan baik, dan apa yang akan dilakukan kemudian seperti dalam penggajian, perencanaan karier, dan lain-lainnya yang tentu saja merupakan salah satu kegiatan yang sangat penting dalam manajemen sumber daya manusia (Hariandja, 2002).

Menurut Handoko (2001), kegunaan-kegunaan penilaian kinerja dapat dirinci sebagai berikut:

1. Perbaikan prestasi kerja

2. Penyesuaian-penyesuaian kompensasi

3. Keputusan-keputusan penempatan

4. Kebutuhan-kebutuhan latihan dan pengembangan

5. Perencanaan dan pengembangan karier

6. Penyimpanan-penyimpanan proses staffing

7. Ketidak-akuratan informasional

8. Kesalahan-kesalahan desain pekerjaan

9. Kesempatan kerja yang adil

10. Tantangan-tantangan eksternal

Salah satu problem dasar yang ditemui oleh perusahaan dalam menilai kinerja karyawan adalah tujuan rangkap (dual purpose) dari penilaian. Satu pihak perusahaan memerlukan evaluasi yang obyektif dari kinerja masa lalu individu dalam membuat keputusan-keputusan personalia. Pihak lain perusahaan membutuhkan alat-alat untuk memungkinkan manajer membantu individu-individu meningkatkan kinerja mereka, merencanakan pekerjaan mendatang,mengembangkan keahlian-keahlian dan kemampuan-kemampuan untuk pertumbuhan karir dan memperkuat kualitas hubungan mereka sebagai manajer dan karyawan (Simamora, 1995).

\section{METODE PENELITIAN}

Variabel yang terdapat dalam penelitian ini meliputi variabel bebasnya adalah kelelahan kerja, kemudian variabel tergantungnya adalah kinerja. Populasi penelitian ini dilakukan di RS. Islam Fatimah Kabupaten Cilacap. Subjek penelitian ini terdiri dari 80 orang, yang terdiri dari perawat yang bertugas di bangsal rawat inap, diambil dri populasi dengan menggunakan tekhnik totality sampling. Alat yang digunakan adalah media kuesioner dengan jumlah lembar kuesioner kelelahan kerja yang terdiri dari 23 pertanyaan dan kuesioner kinerja khususnya kinerja bagi perawat terdiri dari 25 pertanyaan dan telah diuji validitas serta reabilitasnya. Untuk mencari validitas alat ukur dengan menggunakan rumus product moment dan untuk mencarai reabilitas ini digunakan tehnik koefisien Alpha Cronbach. Tekhnis analisis statistic yang dipakai untuk menguji hipotesis yang ditetapkan adalah tehnik chi-square.

\section{HASIL DAN PEMBAHASAN}




\section{A. Hasil Penelitian}

Berdasarkan data hasil penelitian ini terdapat hubungan antara kelelahan kerja dengan kinerja dengan hasil nilai p 0,035 $\leq$ a 0,05 maka Ho ditolak dan $\mathrm{Ha}$ diterima, maka ada hubungan yang signifikan antara kelelahan kerja dengan kinerja. Besarnya hubungan kedua variabel yaitu 2,26\%. Keeratan hubungan antara kelelahan kerja tinggi dengan kinerja yang tidak baik sangat bermakna, tetapi pada kelelahan kerja yang rendah mengalami hubungan yang kurang bermakna karena, mendapatkan hasil kelelahan yang rendah dengan kinerja yang tidak baik. Tingkat kesalahan yang di hasilkan 1,441.

\section{B. Pembahasan}

Berdasarkan hasil penelitian diketahui bahwa perawat di bangsal rawat inap RS Islam Fatimah Cilacap tergolong dalam tingkat kelelahan yang tinggi dengan persentase tingkat kelelahan $63,8 \%$. Hal tersebut disebabkan oleh beberapa faktor penyebab munculnya kelelahan kerja dan kurangnya cara mengatasinya. Dilihat dari tingkatan tugas yang diberikan kepada perawat, meyakinkan bahwa perawat dapat mengalami kelelahan. Beban kerja yang meningkat dilihat dari jumlah pasien yang meningkat. Semakin meningkatnya beban kerja seorang perawat, maka perawat dituntut untuk dapat melaksanakan tugasnya secara maksimal, untuk bekerja secara maksimal seorang perawat harus memiliki keadaan fisik yang memungkinkan. Keadaan fisik seorang perawat dapat dilihat dari umurnya. Dimana umur merupakan factor terpenting penentu keadaan fisik seorang dalam bekerja. Berdasarkan umur perawat di bangsal rawat inap Rumah Sakit Islam Fatimah terdiri dari golongan umur tua (>25 tahun) dengan persentase 66,25\%. Dapat disimpulkan, dengan tingkatan umur perawat di Rumah Sakit Islam Fatimah Cilacap dapat mempengaruhi peningkatan kelelahan kerja.

Berdasarkan hasil tingkat kinerja perawat di bangsal rawat inap Rumah Sakit Islam Fatimah Cilacap tergolong dalam tingkat kinerja yang rendah. Berbagai factor yang dapat mempengaruhi kinerja menurut penelitian ini antara lain kemampuan dalam bekerja. Hasil tingkat kinerja yang tidak baik dapat disebabkan oleh berbagai faktor seperti halnya kemampuan seorang dalam bekerja. Kemampuan/keterampian bekerja seorang perawat dapat dilihat dari tingkatan masa kerjanya serta pendidikannya. Kemampuan seorang karyawan dalam menjalankan pekerjaan atau tugasnya berbeda satu dengan lainnya. Meskipun tugas atau pekerjaanya sama, dikerjakan oleh karyawan yang tingkat pendidikannya sama, tetapi hasilnya berbeda. Hasil pekerjaan karyawan yang satu lebih baik daripada karyawan yang lain, meskipun kesulitan pekerjaan sama dan tingkat pendidikan sama. Perbedaan hasil pekerjaan tersebut disebabkan karena perbedaan kemampuan yang dimiliki oleh karyawan tersebut. Kemampuan karyawan dalam menjalankan tugasnya pada umumnya sejajar dengan prestasinya (Notoatmodjo, 2009).

Hal lain yang dapat mempengaruhi kinerja menurun adalah masa kerja. Didapat hasil tertinggi perawat yang tergolong dalam masa kerja $<6$ tahun berjumlah 37 orang dengan persentase $46,25 \%$. Pada masa kerja tersebut perawat masih tergolong dalam kategori berpengalaman kurang atau kurang mampu dalam bekerja, sehingga tingkat kinerja menjadi tidak baik atau rendah.

Dapat disimpulkan pada penelitian ini menunjukan ada hubungan antara kelelahan kerja dengan kinerja perawat di bangsal rawat inap Rumah Sakit Islam Fatimah Cilacap. Meningkatnya kelelahan dapat memicu menurunnya kinerja, dilihat dari kelelahan tersebut muncul diakibatkan oleh peningkatan pasien setiap periodenya. Peningkatan pasien tersebut dapat menuntut perawat untuk dapat bekerja secara maksimal dan profesional. Perawat 
bekerja dengan maksimal membutuhkan kondisi fisik yang baik agar dapat menyelesaikan tugasnya dengan baik, sedangkan kondisi fisik ada penaruhnya terhadap umur. Perawat yang memiliki tingkat kelelahan tinggi dapat sangat mempengaruhi tingkat kinerjanya. Perawat yang bekerja terus menerus dapat menimbulkan kelelahan dan mengakibatkan penurunan tingkat kinerja. Menurut observasi yang dialakukan peneliti, perawat mengalami kelelahan akibat terlalu jauhnya jarak tempat kerja dengan tempat tingkal mereka, selain itu, adanya peningkatan pasien setiap harinya. Secara keperawatan, perawat rawat inap di berikan tanggung jawab untuk dapat melayani satu pasien, tetapi karena faktor meningkatnya pasien, maka perawat mengalami peningkatan beban kerja dengan menanggung pasien lebih dari satu. Hal ini dapat menimbulkan rasa kelalahan meningkat, dan dapat pula mempengaruhi hasil kerja mereka.

Rendahnya kinerja seorang pekerja tidak hanya ditimbulkan oleh beban kerja maupun umur mereka, tetapi dilihat pula dari tingkat kemampuan/ keterampilan kerja mereka. Dilihat dari hasil tingkat pendidikan pada perawat di bangsal rawat inap Rumah Sakit Islam Fatimah sebagian besar berpendidikan Diploma 3, secara umum pendidikan Diploma 3 tidak selamanya tingkat kinerjanya tidak baik dibandingan dengan Sarjana yang tergolong pendidikan di atasnya, dilihat kembali bagaimana keterampilan/kemampuan pekerja tersebut dalam bekerja.

\section{SIMPULAN DAN SARAN}

\section{A. Simpulan}

1) Tingkat kelelahan kerja perawat di bangsal rawat inap Rumah Sakit Islam Fatimah Cilacap sebesar $63,8 \%$, dan tergolong dalam tingkat kelelahan yang tinggi.

2) Tingkat kinerja perawat di bangsal Rumah Sakit Islam Fatimah sebesar persentase $67,5 \%$, dan tergolong dalam tingkat kinerja yang tidak baik.

3) Ada hubungan antara kelelahan kerja dengan kinerja perawat di bangsal rawat inap Rumah Sakit Islam Fatimah Cilacap.

\section{B. Saran}

1) Perlunya penambahan sumber daya manusia berupa perawat untuk dapat meringankan beban kerja perawat di bangsal rawat inap yang meningkat.

2) Perlunya pelatihan bagi perawat yang belum lama berpengalaman kerja untuk dapat meningkatkan kinerja keperawatan dan dapat diperpanjang kontraknya sehingga dapat bekerja lebih lama di RS Islam Fatimah Kabupaten Cilacap.

\section{DAFTAR PUSTAKA}

1. Azwar, S., 2007, Penyusunan Skala Psikologi, Pustaka Pelajar Offset, Yogyakarta

2. Depkes RI., 2001. Standar Tenaga Keperawatan Di Rumah Sakit. Departemen Kesehatan RI, Jakarta. Hal 1-2

3. Eraliesa, F., 2009, Hubungan Foktor Individu Dengan Kelelahan Kerja Pada Tenaga Kerja Bongkar Muat Di Pelabuhan Tapaktuan Kecamatan Tapaktuan Kabupaten Aceh Selatan, Skripsi, Fakultas Kesehatan Masyarakat, Universitas Sumatera Utara, Medan 
4. Faizin, A., Winarsih., 2008, Hubungan Tingkat Pendidikan Dan Lama Kerja Perawat Dengan Kinerja Perawat Di RSU Pandan Arang Kabupaten Boyolali, Berita IImu Keperawatan ISSN vol 1(3): Pp. 137-142

5. Handoko, H., 2001, Manajemen Personalia dan Manajemen Sumber Daya Manusia, BPFE, Yogyakarta. Hal 135-137, 151-152

6. Hariandja, E., 2002, Manajemen Sumber Daya Manusia (Pengadaan, Pengembangan, Pengkompensasian, dan Peningkatan Produktivitas Pegawai). PT Garasindo Ikapi, Jakarta. Hal 195

7. Hasibuan, 2010, Manajemen Sumber Daya Manusia, Bumi Aksara, Jakarta. Hal. 54

8. Mangkunegara, A, P., 2009, Manajemen Sumber Daya Manusia Perusahaan, PT. Remaja Rosdakarya, Bandung. Hal 69

9. Mayasari, A., 2011, Perbedaan Tingkat Kelelhan Perawat Shit Pagi Dengan Shift Malam, Jurnal Kesehatan Masyarakat vol 7 (1), UNES. Pp. 32-38

10. Mumpuni, A., Wulandari, 2010, Cara Jitu Mengatasi Stress, Andi Offset, Yogyakarta. Hal 103

11. Nitisemito, A, S., 1996, Manajemen Personalia : Manajemen Sumber Daya Manusia, Cetakan ke 9, Ghalia Indonesia, Jakarta. Hal 221

12. Nitisemito, A, S., 1988, Manajemen Personalia : Manajemen Sumber Daya Manusia, Cetakan ke 7, Ghalia Indonesia, Jakarta. Hal 131-133

13. Notoatmodjo, S., 2010, Metode Penelitian Kesehatan, Rineka Cipta, Jakarta. Hal 37-38

14. Notoatmodjo, S., 2003, Pengenbangan Sumber Daya Manusia, Rineka Cipta, Jakarta. Hal 146-149

15. Notoatmodjo, S., 2009, Pengembangan Sumber Daya Manusia, Rineka Cipta, Jakarta. Hal 2,136-137

16. Notoatmodjo, S., 2007, Promosi Kesehatan dan Ilmu Perilaku, Rineka Cipta, Jakarta. Hal 229

17. Nurmianto, E., 1996, Ergonomi konsep Dasar dan Aplikasinya, ITSN. Hal 264

18. Pabundu, Tika, 2006, Budaya Organisasi dan Peningkatan Kinerja Perusahaan, Bumi Aksara, Jakarta. Hal 121

19. Setyawati L.M, Endang S, Wijaya, 2006, Hubungan Shift Kerja Dengan Gangguan Tidur Dan Kelelahan Kerja Perawat Instalasi Rawat Darurat RS DR. Sardjito Yogyakarta, Sains Kesehatan vol 19(2). Pp. 235-245

20. Setyawati, L. M., 2010, Selintas Tentang Kelelahan Kerja, Amara Books, Yogyakarta. Hal 28-33

21. Simamora, H., 1995, Manajemen Sumber Daya Manusia, STIE YKPN, cetakan 1, Yogyakarta. Hal 330

22. Siagian, S., 2010, Manajemen Sumber Daya Manusia, Bumi Aksara, Jakarta. Hal 223-224

23. Sostrohadiwiryo, S., 2005, Manajemen Tenaga Kerja Indonesia (Pendekatan Administratif dan operasional), Bumi Aksara, Jakarta. Hal 231

24. Suma'mur, P. K., 1995, Ergonomi Untuk Produktivitas Kerja, Gunung Agung, Jakarta. Hal 68-68, 70

25. Sugiyono, 2009, Metode Penelitian Bisnis, Alfabeta, Bandung. Hal 94-95

26. Sugiyono, 2010, Metode Penelitian Bisnis, Alfabeta, Bandung. Hal 314-418

27. Wibowo. S. E., M. Phil., 2010, Manajemen Kinerja, Edisi ke 3, Rajawali Press, Jakarta. Hal 7

28. Wirawan., 2009, Evaluasi Kinerja Sumber Daya Manusia (Teori, Aplikasi, dan Penelitian), Salemba Empat, Jakarta. Hal 6-7

29. Yanuk, Wulandari., 2009, Hubungan antara Beban Kerja, Stres Kerja dan Tingkat Konflik Dengan Kelelahan Kerja Perawat di Rumah Sakit Islam Yogyakarta PDHI Kota Yogyakarta, Skripsi, Fakultas Kesehatan Masyarakat, Universitas Ahmad Dahlan, Yogyakarta. Hal 69 